\title{
VALUATION OF SECOND PILLAR PENSION PRODUCTS IN SLOVAKIA
}

\author{
JANA ŠPIRKOVÁ, IGOR KOLLÁR
}

Matej Bel University, Faculty of Economics, Department of Quantitative Methods and Information Systems,

Tajovského 10, 97590 Banská Bystrica, Slovakia

email: jana.spirkova@umb.sk, igor.kollar@umb.sk

\section{GÁBOR SZÛ́CS}

Comenius University, Faculty of Mathematics, Physics and Informatics,

Department of Applied Mathematics and Statistics, Mlynská dolina, 84248 Bratislava, Slovakia email: Gabor.Szucs@fmph.uniba.sk

\section{MÁRIA SPIŠIAKOVÁ}

Matej Bel University, Faculty of Economics, Department of Language Communication in Business,

Tajovského 10, 97590 Banská Bystrica, Slovakia

email: maria.spisiakova@umb.sk

\begin{abstract}
This paper presents selected products of the payout phase of the second pillar pension scheme in the Slovak Republic which are stated by Act 43/2004 Coll. on the Old-Age Pension Saving Scheme and on amendments to some acts. By means of stochastic modeling of the force of mortality, it models and analyses the amounts of pension annuities in the selected designed products of the second pillar pension saving according to the requirements of the Council Directive 2004/113/EC, which sets the rules on gender-neutral pricing in insurance, and of the Council Directive 2009/138/EC, which, among other things, sets also the rules relating to the technical provisions, Solvency Capital Requirement, Minimum Capital Requirement and investment rules.
\end{abstract}

Key words: annuity, product, force of mortality, technical interest rate, gender

JEL Codes: C15, C61, G22, K10

DOI: 10.15611/amse.2017.20.36

\section{Introduction}

Old-age pension saving in the Slovak Republic represents a capitalization, so-called second pillar of the pension scheme based on contributions. This means that the amount of pension will depend on the contributions paid to the second pillar and their appreciation. The funds of the savers are managed by pension funds management companies (in Slovak Dôchodková správcovská spoločnost' - DSS). A pension funds management company is a joint stock company based in the Slovak Republic which deals with creating and managing pension funds to carry out old-age pension saving. Each pension funds management company can be established and run only with an authorization from the National Bank of Slovakia.

The area of old age pension saving is regulated by Act 43/2004 Coll. on the Old-Age Pension Saving Scheme as amended by some acts in the wording of later regulations (hereinafter Act), 
with effect from January 1, 2016.

The first pensions from the old-age pension saving system started to be paid out on January 1, 2015, when it turned out that a few issues had to be revised in the Act. One of the benefits for the savers is that they can buy an annuity in a life insurance company which was granted a licence to pay pensions from old-age pension saving. The savers can also have the value of the amount saved increased and use it as a life insurance, in which case the amount saved can be inherited if the saver dies. Article 40 paragraph 1 of the Act says that "the authorised person designated by the saver in an old-age pension scheme agreement shall, upon the death of the saver, become entitled to the payment of an amount corresponding to the current value of the deceased saver's personal pension account as at the date on which the pension funds management company learnt of the saver's death, with this amount to be reduced by the amount of undue mandatory contributions transferred on behalf of the deceased saver and requested back by the Social Insurance Agency and by the amount of legitimate expenditures of the pension funds management company incurred in relation to the payment of the amount in cash or its transfer to a non-euro area country, and increased by the amount of mandatory contributions that the Social Insurance Agency has still to transfer. Where a saver has not designated an authorised person in the old-age pension scheme agreement, or no such person exists, the assets in the saver's personal pension account shall become the subject of inheritance proceedings." The Social Insurance Agency has established a so-called Central Information Offer System (in Slovak Centrálny informačný ponukový systém - CIPS) to mediate relevant pension offers for the savers. This register will guarantee transparency of the system and reduce the administrative burden of the savers, who will get all offers at one point. This allows the saver to compare easily the offers of individual insurance companies. The introduction of the Register has eliminated the intermediary business in pension payment, which increased the price of pension by the commission cost incurred. It has also established a competitive environment, which brings a positive effect on the amount of pensions paid.

The aim of our paper is to model and analyse the products by which it would be possible to determine the amount of pension on the basis of a future pensioner's own choice. Moreover, we analyse the amount of future pensions with respect to some risk factors, such as force of mortality, costs, gender and technical interest rate.

For analysis of the products we use life tables from the web page of the Statistical Office of the Slovak Republic, Life tables (2017). These tables represent a corner stone of actuarial modelling of the force of mortality and subsequently the probability of survival or the probability of death. Individual products were created on the basis of models found in Dickson, D. C. M. et al. (2009) and their description can be found in Article 46 of Act 43/2004 Coll.

The amount of pensions can be significantly affected by the cost of pension administration and payment by life insurance companies. The establishment of the Central Information Offer Register has abolished the obligation of insurance companies to calculate mostly high commissions paid to insurance consultants, which were then subtracted from the amount of savings.

The European Union (EU) Gender Directive (Council Directive 2004/113/EC) guarantees equal treatment between men and women in the access and supply of goods and services. However, the Directive does not prohibit insurers from using gender in the calculation of premiums and benefits, as it contains an exemption to this rule: under Article 5(2), "Member States can opt out from banning the use of gender and can allow "proportionate differences" in insurance premiums and benefits, where the use of gender is a determining factor in the assessment of risk based on the relevant and accurate actuarial and statistical data, provided that Member States 
ensure that such data is compiled, published and regularly updated." All European national legislative assemblies chose to use the opt-out for life products - including life insurance and pension annuities. However, on March 1, 2011, the European Court of Justice (ECJ) ruled that this time-unlimited opt-out provision from the EU Gender Directive was inconsistent with the European Charter (Test-Achats ruling 1 ). The ECJ ruled that the (time-unlimited) exemption is invalid but allowed for a transition period for implementation up to December, 21, 2012. National governments of Member States were obliged to change their laws accordingly by that date. For more information, see Oxera (2012) and The Impact of a Ban on the Use of Gender in Insurance (2012).

Not only the risk factors - gender and regulation of ECJ, but also trends in the development of technical interest rate can affect the amount of pension annuities. Technical interest rate currently valid in the Slovak Republic is $0.7 \%$ p. a., see National Bank of Slovakia (2016). This maximum technical interest rate holds only for insurance companies which act in a socalled special regime. It concerns "small" companies which are not governed by the new rules of Solvency II. For other companies the National Bank of Slovakia does not set the maximum interest rate any more. Instead, these companies use bond yield curves and the National Bank of Slovakia controls and approves the whole internal model and its parameters, including the parameters of yield curves. Naturally, an integral part of the calculation of pension annuities are administrative costs, too.

We would like to emphasize that our results do not express real monthly pensions which insurance companies could pay out, because in our approach, we did not consider the longevity of pensioners and the variable structures of risk-free interest rates. Our results illustrate the differences between six products and between the entry pensioner ages from 62 to 72 years. Moreover, we discuss the impact of the individual costs on an amount of pension annuities.

This paper is divided into five parts. In Section 2, we mention basic paragraphs of the Act which are related with individual products arising from payout phase of the old pension saving and basic concepts of pension annuity modelling. Section 3 contains models of all products which are defined in Section 2. In Section 4, we offer analysis of the mentioned products with focus on costs, technical interest rate in the Slovak Republic and gender with regard to the requirements of the European Court of Justice. At the end, in the fifth part, we give conclusions and some remarks and schemes of our further investigation.

\section{Preliminaries}

\subsection{The Offer of Life Old-age Pension Stated by the Act}

In our paper we focus on modeling and analysis of life old-age pension and life early retirement pension pursuant to Article 46 of the Act.

This article says that the insurer will draw up an offer of old-age annuity or early retirement annuity for the saver on the date of issue of the certificate through the Offer System. The possible products for the saver to choose from are as follows:

- Product 1 - includes permanent monthly annuity and the payment of a lump sum equal to not yet paid monthly annuities in the case of the beneficiary's death during the period of

\footnotetext{
${ }^{1}$ The ruling arose from a legal challenge from the Association Belge des Consommateurs test - Achats ASBL, a Belgian consumer association, about whether the exemption is compatible with the prohibition on discrimination on the grounds of gender.
} 
the first seven years of pension payment (does not include raising of the pension and does not include survivors' benefits),

- Product 2 - includes permanent monthly annuity with (geometrically) raising annuity by $z \%$ yearly, and it includes also the payment of a lump sum which is the sum of not yet paid monthly annuities in the case of the beneficiary's death during the period of the first seven years of pension payment (does not include survivors' benefits),

- Product 3 - includes permanent monthly annuity and the payment of a lump sum equal to not yet paid monthly annuities in the case of the beneficiary's death during the period of the first seven years of pension payment, and includes survivors' benefits with a payment period of one year,

- Product 4 - includes permanent monthly annuity and the payment of a lump sum equal to not yet paid monthly annuities in the case of the beneficiary's death during the period of the first seven years of pension payment, and includes survivors' benefits with a payment period of two years,

- Product 5 - includes permanent monthly annuity with (geometrically) raising annuity by $z \%$ yearly, and it includes also the payment of a lump sum which is the sum of not yet paid monthly annuities in the case of the beneficiary's death during the period of the first seven years of pension payment, and includes raising of the pension and includes survivors' benefits with a payment period of one year,

- Product 6 - includes permanent monthly annuity with (geometrically) raising annuity by $z \%$ yearly, and it includes also the payment of a lump sum which is the sum of not yet paid monthly annuities in the case of the beneficiary's death during the period of the first seven years of pension payment, and includes raising of the pension and includes survivors' benefits with a payment period of two years.

Article 42 of the Act, which rules the increasing of annuities, states that where it is agreed in a pension insurance contract to raise the old-age annuity or early retirement annuity, the increase shall be carried out each year on the same date on which the insurer's obligation to perform the contract arises and by the percentage rate applicable as at the submission date of the offer mentioned in Article 46. The percentage rate of increase of pensions under paragraph 1 may be set by the National Bank of Slovakia in a decree to be published in the Collection of Laws of the Slovak Republic.

\subsection{Basic Concepts of Pension Annuity Modelling}

Pension annuity contracts offer a regular series of payments. If the pension annuity continues until the death of the annuitant, it is called a whole life annuity or perpetuity. The buying of a whole life annuity guarantees that the income will not run out before the annuitant dies. In this part we show how probabilities of survival or death can be calculated under the framework of life insurance.

Let $(x)$ denote an age at entry $x$, where $x \geq 0$. The death of $(x)$ can occur at any age greater than $x$, and we can model so-called future lifetime of $(x)$ by a continuous random variable $T_{x}$.

First, we will define basic quantity known as the force of mortality. A fundamental building 
block of our investigation are mortality tables from the year 2015 which are published on the web page of the Statistical Office of the Slovak Republic, Life tables (2017) or The Human Mortality Database (2017), respectively. The force of mortality is a fundamental concept in modelling future lifetime. We denote the force of mortality at age $x$ by $\mu_{x}$ and we define it as Dickson, D. C. M. et al. (2009, 17-26).

$$
\mu_{x}=\lim _{d x \rightarrow 0^{+}} \frac{1}{d x} \operatorname{Pr}\left[T_{x} \leq d x\right]
$$

On the basis of the number of living and dying we determine an estimation of the force of mortality by the formula

$$
m_{x}=\frac{D_{x}}{P_{x}}
$$

where $D_{x}$ is the number of dying at age $x$ and $P_{x}$ is the number of living at age $x$.

Throughout this paper we illustrate our results on the Standard Survival Model using Makeham's law, which models the force of mortality as follows:

$$
\mu_{x}=A+B \cdot c^{x}
$$

where $A, B$ and $c$ are constants and $x$ is entry age of individual.

We will summarize the relevant actuarial notation for survival and mortality probabilities:

- ${ }_{t} p_{x}$ is the probability that individual $(x)$ survives to at least age $x+t$,

- ${ }_{t} q_{x}$ is the probability that individual $(x)$ dies before age $x+t$,

- ${ }_{r \mid t} q_{x}$ is the probability that individual $(x)$ survives $r$ years, and then dies in the subsequent $t$ years, that is, between ages $x+r$ and $x+r+t$.

Following Dickson, D. C. M. et al. (2009, 26-27), we can derive ${ }_{t} p_{x}$ as follows

$$
{ }_{t} p_{x}=\exp \left\{-\int_{x}^{x+t} \mu_{r} \mathrm{~d} r\right\}
$$

Using expressions (3) and (4) we obtain ${ }_{t} p_{x}$

$$
{ }_{t} p_{x}=\exp \left\{-A t-\frac{B \cdot c^{x}}{\log c}\left(c^{t}-1\right)\right\},
$$

and subsequently, we can model the probability of survival and probability of death with $t=$ $1 / 12$. Constants $A, B$ and $c$ can be obtained by modeling of the force of mortality using IBM SPSS Statistics 21 system.

Table 1: Constants of the Standard Survival Model Using Life Tables 2015

\begin{tabular}{cccc}
\hline & $A$ & $B$ & $c$ \\
\hline Unisex & 0.001433 & 0.00001293 & 1.113202 \\
Male & 0.000000 & 0.0000689 & 1.094054 \\
Female & 0.000000 & 0.000004338 & 1.126396 \\
\hline
\end{tabular}

Source: the authors 
Table 2: Standard Survival Model Using Formula (5)

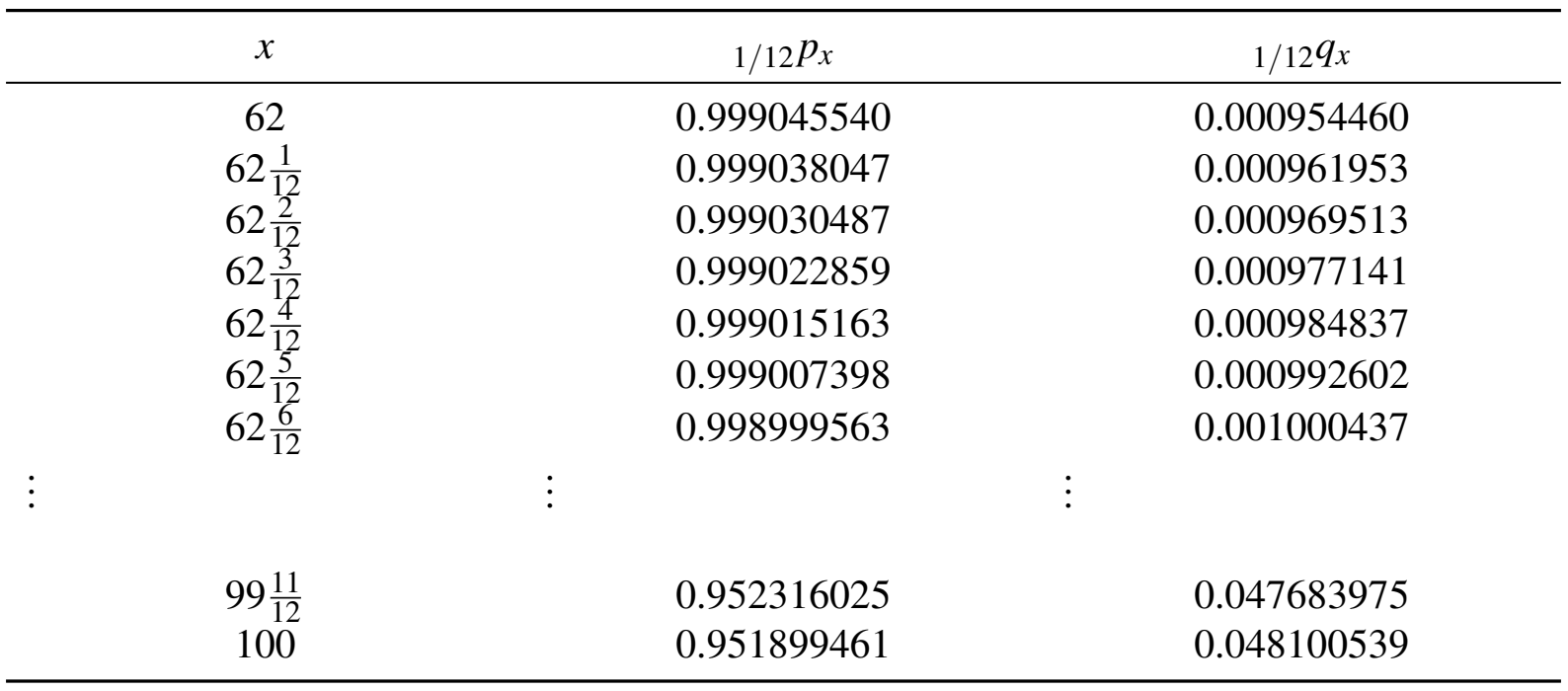

Source: the authors

\section{Products of the Second Pillar Pension}

In this section, we offer models of individual products which are determined by the Act, in the order as they are listed above, see Section 2. These products models include whole life annuities and also inheritance in the payout phase and so-called survivor's benefits.

Inheritance in the Payout Phase In case the beneficiary of whole life old-age annuities dies during the first seven years of payment, the rest of the sum to be paid during this period will be paid to a person designated by the saver in the old-age pension agreement. If there is no such person, the amount designated for the payment shall become the subject of inheritance proceedings.

Survivor's Benefits The saver can arrange also survivor's benefits in their old-age pension agreement. In case of death of the beneficiary of whole life old-age annuities the life insurance company will pay the survivor (widow, widower, orphan) a survivor's pension during the agreed period, which is one or two years. First we will give basic notations which are used in formulas of individual products:

- $S$ - accumulated sum, gross single premium (the saver's pension savings);

- $i$ - technical interest rate as a \% p.a.;

- $m$ - number of paid, or paid out annuities within one year;

- $x$ - retirement age;

- $n$ - number of years of term pension;

- $\omega$ - maximum age to which a person can live to see (regarding used life tables is here $\omega=100$; 
- $z$ - rate of geometrically increasing annuity as a \% from yearly regular annuity;

- $\alpha$ - initial costs as a \% from accumulated sum;

- $\beta$ - administrative costs as a \% from yearly regular annuity;

- $\delta_{1}$ - collection costs as a $\%$ from yearly regular annuity;

- $\delta_{2}$ - collection costs as a $\%$ from sum of guaranteed annuities;

- $\delta_{3}$ - collection costs as a $\%$ from accumulated sum, essential to the termination of the contractual relationship during the first month, when the client was not entitled to get the first pension yet.

Product 1 This product contains permanent monthly annuity and payment of a lump sum equal to not yet paid monthly annuities in the case of the beneficiary death during the period of the first seven years of pension payment. Monthly pension annuity $M P_{1}$ of this product is given by formula

$$
M P_{1}=\frac{S \cdot\left(1-\left.A_{x: \overline{1 / 12}}\right|^{(12)} \cdot\left(1-\frac{\delta_{3}}{100}\right)-\frac{\alpha}{100}\right)}{12 \cdot\left(a_{x}^{(12)} \cdot\left(1+\frac{\beta}{100}+\frac{\delta_{1}}{100}\right)+(G a)_{x: 71}(12) \cdot\left(1+\frac{\delta_{2}}{100}\right)\right)}
$$

where

$$
\begin{gathered}
v=\frac{1}{1+\frac{i}{100}}, \\
A_{x: \overline{1 / 12}}(12)={ }_{\frac{1}{12}} q_{x} v^{\frac{1}{12}} \\
a_{x}^{(12)}=\sum_{r=1}^{12(\omega-x)} \frac{1}{12} \frac{r}{12} p_{x} \cdot v^{\frac{r}{12}}
\end{gathered}
$$

is expected present value of whole life benefits in advance of $1 / 12$ of monetary units (m.u.), 12-times per year, conditional upon the client life, and

$$
(G a)_{x: 71}^{(12)}=\sum_{r=1}^{83} \frac{84-r}{12} \cdot \frac{r}{12} \mid \frac{1}{12} q_{x} \cdot v^{\frac{r+1}{12}}
$$

is expected present value of the sum of not yet paid monthly annuities in the case of the beneficiary death during the period of the first seven years of pension payment.

Product 2 The difference between Product 2 and Product 1 is in that in Product 2 we consider a whole life pension annuity with (geometrically) raising annuity by $z \%$ yearly, and it includes also the payment of a lump sum which is the sum of not yet paid monthly annuities in the case of the beneficiary death during the period of the first seven years of pension payment. Monthly pension annuity is as follows

$$
M P_{2}=\frac{S \cdot\left(1-A_{x: \overline{1 / 12}}(12) \cdot\left(1-\frac{\delta_{3}}{100}\right)-\frac{\alpha}{100}\right)}{12 \cdot\left((I a)_{x}^{z(12)} \cdot\left(1+\frac{\beta}{100}+\frac{\delta_{1}}{100}\right)+(I G a)_{x: 7}^{\left.z l^{z(12)} \cdot\left(1+\frac{\delta_{2}}{100}\right)\right)}\right.}
$$


where

$$
(I a)_{x}^{z(12)}=\sum_{r=0}^{\omega-x-1}\left(1+\frac{z}{100}\right)^{r}{ }_{r} p_{x} \cdot v^{r} \cdot a_{x+r: 1_{1}^{(12)}}
$$

where

$$
a_{x+r: \overline{1}^{(12)}}=\sum_{j=1}^{12} \frac{1}{12} \cdot \frac{j}{12} p_{x+r} \cdot v^{\frac{j}{12}}
$$

represents the expected present value of individual benefits of 1/12 m.u. 12-times per year, raising by $z \%$ yearly, and

$$
\begin{aligned}
& (I G a)_{x:\left.7\right|^{z(12)}=} \\
= & \sum_{j=0}^{11} \sum_{n=1}^{7}\left\{\frac{(n-1) 12+j}{12} \mid \frac{1}{12} q_{x} \cdot v^{\frac{(n-1) 12+j+1}{12}} \cdot\left[\left(1+\frac{z}{100}\right)^{n-1} \cdot \frac{12-j}{12}+\left(1+\frac{z}{100}\right)^{n} \cdot \frac{\left(1+\frac{z}{100}\right)^{7-n}-1}{\frac{z}{100}}\right]\right\}- \\
- & \frac{1}{12} \cdot \frac{1}{12} q_{x} \cdot v^{\frac{1}{12}}\left(\left(1+\frac{z}{100}\right) \frac{\left(1+\frac{z}{100}\right)^{6}-1}{\frac{z}{100}}+1\right)
\end{aligned}
$$

is the expected present value of not yet paid monthly annuities in the case of the beneficiary death during the period of the first seven years of pension payment.

Products 3 and 4 Products 3 and 4 represent Product 1 with the addition of survivor's benefits that are guaranteed to be paid to the survivors during one (Product 3) or two (Product 4) years. i.e. $n=1$ or $n=2$.

Monthly pension annuity for the mentioned products is

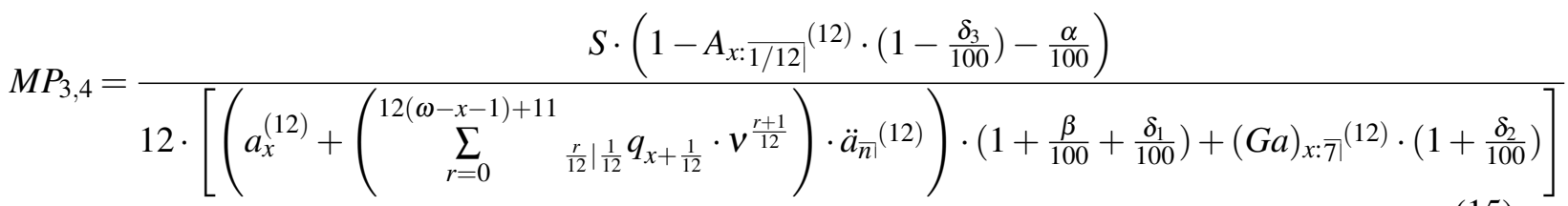

where

$$
\ddot{a}_{\bar{n} \mid}{ }^{(12)}=\frac{1}{12} \cdot \frac{v^{n}-1}{v^{\frac{1}{12}}-1}
$$

is present value of an annuity-certain of $1 / 12$ of one m.u. payable monthly in advance for $n$ years. See, e.g. Urbaníková, M., Maroš, M. (2014).

Products 5 and 6 These products represent Product 2 extended by inheritance pension during one (Product 5) or two (Product 6) years. Precisely, the mentioned products represent whole life pension annuity with raising annuity and with inherited annuities with term payment of one or two years.

Monthly pension annuity is given by

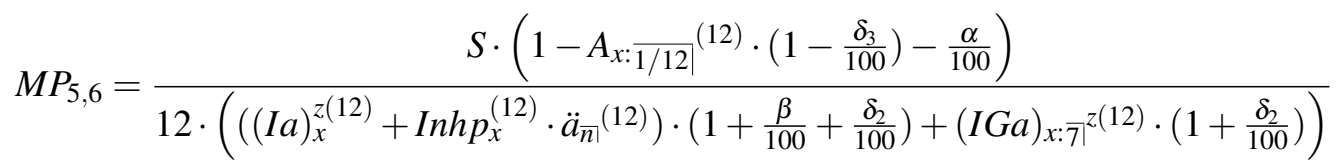


where

$$
\operatorname{Inh} p_{x}^{(12)}=\sum_{j=0}^{11} \sum_{r=0}^{\omega-x-1}\left(1+\frac{z}{100}\right)^{r} \cdot r p_{x} v^{r} \cdot \frac{j}{12} \mid \frac{1}{12} q_{x+r} \cdot v^{\frac{j+1}{12}}-{ }_{\frac{1}{12}} q_{x} \cdot v^{\frac{1}{12}}
$$

is the expected present value of whole life benefits in the case of death of the pensioner.

\section{Analysis of Individual Products}

Net and also gross monthly pension annuities for all proposed products are evaluated for unisex mortality tables 2015 (see Life tables (2017)), Makeham's law (see Tables 1 and 2), retirement ages $x=(62-72)$ years and saved accumulated sum $S=10,000$ euros, with raising annuity by $z=0.5 \%$ yearly, inherited pension annuities during $n=1$ or 2 years. Monthly net and gross pension annuities can be found in Tables 3, 4 and 5. Gross monthly pension annuities are evaluated for two types of costs which are determined as follows:

- type A: $\alpha=8 \%$ from accumulated sum, $\beta=0.5 \%$ from yearly annuity, $\delta_{1}=0.2 \%$ from yearly annuity, $\delta_{2}=0.3 \%$ from single paid annuities and $p=0.1 \%$ from accumulated sum;

- type B: $\alpha=4 \%$ of the accumulated sum, $\beta=0.3 \%$ of yearly annuity, $\delta_{1}=0.2 \%$ of yearly annuity, $\delta_{2}=0.1 \%$ of single paid annuities and $p=0.05 \%$ from accumulated sum.

Table 3: The amount of net monthly whole life pension annuities (euros) according to retirement age with accumulated sum 10,000 euros and technical interest rate $0.7 \%$ p. a.

\begin{tabular}{ccccccc}
\hline$x$ & $M P_{1}$ & $M P_{2}$ & $M P_{3,4}$ & $M P_{3,4}$ & $M P_{5,6}$ & $M P_{5,6}$ \\
& & & $n=1$ & $n=2$ & $n=1$ & $n=2$ \\
\hline 62 & 46.61 & 44.22 & 44.44 & 42.47 & 42.08 & 40.15 \\
63 & 48.34 & 45.95 & 46.00 & 43.88 & 43.64 & 41.57 \\
64 & 50.18 & 47.78 & 47.64 & 45.37 & 45.29 & 43.07 \\
65 & 52.11 & 49.72 & 49.37 & 46.92 & 47.04 & 44.64 \\
66 & 54.16 & 51.77 & 51.19 & 48.55 & 48.87 & 46.29 \\
67 & 56.33 & 53.94 & 53.11 & 50.25 & 50.80 & 48.02 \\
68 & 58.62 & 56.23 & 55.12 & 52.04 & 52.83 & 49.83 \\
69 & 61.02 & 58.64 & 57.23 & 53.90 & 54.95 & 51.72 \\
70 & 63.55 & 61.18 & 59.43 & 55.83 & 57.18 & 53.69 \\
71 & 66.20 & 63.85 & 61.72 & 57.83 & 59.50 & 55.74 \\
72 & 68.92 & 66.63 & 64.10 & 59.90 & 61.92 & 57.86 \\
\hline
\end{tabular}

Source: the authors 
Table 4: The amount of gross monthly whole life pension annuities (euros) according to retirement age with accumulated sum 10,000 euros and technical interest rate 0.7\% p. a., type of $\operatorname{costs} A$.

\begin{tabular}{lcccccc}
\hline$x$ & $M P_{1}$ & $M P_{2}$ & $M P_{3,4}$ & $M P_{3,4}$ & $M P_{5,6}$ & $M P_{5,6}$ \\
& & & $n=1$ & $n=2$ & $n=1$ & $n=2$ \\
\hline 62 & 42.59 & 40.40 & 40.60 & 38.80 & 38.44 & 36.68 \\
63 & 44.17 & 41.98 & 42.02 & 40.09 & 39.87 & 37.98 \\
64 & 45.84 & 43.65 & 43.53 & 41.45 & 41.38 & 39.35 \\
65 & 47.61 & 45.42 & 45.11 & 42.87 & 42.97 & 40.79 \\
66 & 49.49 & 47.30 & 46.77 & 44.36 & 44.65 & 42.29 \\
67 & 51.46 & 49.28 & 48.52 & 45.91 & 46.41 & 43.87 \\
68 & 53.55 & 51.37 & 50.36 & 47.54 & 48.26 & 45.53 \\
69 & 55.75 & 53.58 & 52.28 & 49.24 & 50.21 & 47.26 \\
70 & 58.06 & 55.90 & 54.29 & 51.01 & 52.24 & 49.06 \\
71 & 60.49 & 58.33 & 56.39 & 52.84 & 54.36 & 50.92 \\
72 & 63.02 & 60.88 & 58.57 & 54.73 & 56.57 & 52.86 \\
\hline
\end{tabular}

Source: the authors

Table 5: The amount of gross monthly whole life pension annuities (euros) according to retirement age with accumulated sum 10,000 euros and technical interest rate $0.7 \%$. a., type of costs $B$.

\begin{tabular}{ccccccc}
\hline$x$ & $M P_{1}$ & $M P_{2}$ & $M P_{3,4}$ & $M P_{3,4}$ & $M P_{5,6}$ & $M P_{5,6}$ \\
& & & $n=1$ & $n=2$ & $n=1$ & $n=2$ \\
\hline 62 & 44.59 & 42.30 & 42.51 & 40.63 & 40.25 & 38.41 \\
63 & 46.25 & 43.95 & 44.00 & 41.98 & 41.75 & 49.77 \\
64 & 48.00 & 45.71 & 45.58 & 43.40 & 43.33 & 41.20 \\
65 & 49.86 & 47.56 & 47.23 & 44.89 & 45.00 & 42.71 \\
66 & 51.82 & 49.53 & 48.98 & 46.45 & 46.75 & 44.29 \\
67 & 53.89 & 51.60 & 50.81 & 48.07 & 48.60 & 45.94 \\
68 & 56.07 & 53.79 & 52.73 & 49.78 & 50.54 & 47.67 \\
69 & 58.38 & 56.10 & 54.75 & 51.56 & 52.57 & 49.48 \\
70 & 60.80 & 58.53 & 56.85 & 53.41 & 54.70 & 51.37 \\
71 & 63.33 & 61.08 & 59.05 & 55.33 & 56.93 & 53.52 \\
72 & 65.99 & 63.75 & 61.33 & 57.31 & 59.24 & 55.35 \\
\hline
\end{tabular}

Source: the authors

Based on the data available for the Slovak Republic, with technical interest rate $0.7 \%$ p. a monthly pension with types of costs A could see a reduction in pension income from pension annuities of around $9.0 \%$ on average; a monthly pension with types of costs B could see a pension income reduction by around $4.0 \%$ on average in comparison with net monthly pension (with zero costs).

Based on the data available for the Slovak Republic, with technical interest rate $0.7 \%$ p. a. men 
(aged 62) could see a reduction in pension income from pension annuities of around $10 \%$ on average; women (aged 62) could see a pension income rise by around $7 \%$ on average.

\section{Conclusion}

In this paper, we have analyzed products of the second pillar pension related to payout phase, namely those products which are defined in Article 46 of Act 43/2004 Coll.

Individual products have been modelled using the expected present values of corresponding benefits. These products are influenced by a lot of factors and we have focused on the impact of the force of mortality, administrative costs, technical interest rate and gender.

We have considered constant technical interest rate. In future, we intend to continue further and investigate the impact of yield curve and inflation on the amount of monthly pension annuities according to Directive 2009/138/EC of the European Parliament and of the Council, which is known as Solvency II. We also plan to study the impact of the force of mortality from statistical point of view, which we would like to model by fractional age assumption using basic mortality tables and Balducci's assumption, e.g. Potocký $(2012,38)$.

Another issue that could be worth of our interest in future is annuity modeling according to Albrecher et al. (2016), Deprez, P. et al. (2017), Chen, L. et al. (2017), Konicz et al. (2015a) and (2015b) and other papers, e.g. the Consultation paper of the European Insurance and Occupational Pensions Authority - (EIOPA) (2015) about a pan-European personal pension product.

\section{Acknowledgements}

Jana Špirková and Igor Kollár have been supported by the Slovak Scientific Grant Agency VEGA NO. 1/0093/17 Identification of risk factors and their impact on products of the insurance and saving schemes.

Gábor Szúcs has been supported by the Slovak Scientific Grant Agency VEGA NO. 2/0047/15 Discrete and continuous probabilistic models and their applications.

\section{References}

[1] Act 43/2004 Coll. on the Old-Age Pension Saving Scheme and on amendments to some acts. [cit. 24-03-2017], https: //www.slov-lex.sk/pravne-predpisy/SK/ZZ/2004/650/.

[2] Albrecher, H. et al. 2016. Old-age provision: past, present, future. Eur. Actuar. J. vol. 6, iss. 2, pp. 287-306. doi:10.1007/s13385-016-0136-9.

[3] Deprez, P. et al. 2017. Machine learning techniques for mortality modeling. Eur. Actuar. J., vol. 7, iss. 15, pp. 1-16. doi:10.1007/s13385-017-0152-4.

[4] Dickson, D. C. M. et al. 2009. Actuarial Mathematics for Life Contingent Risks. New York: Cambridge University Press. ISBN 978-0-521-11825-5.

[5] Consultation paper on the creation of a standardized PanEuropean personal pension product 2015. [cit. 15-09-2015], 
https://eiopa.europa.eu/Publications/Consultations/EIOPA-CP-15-006-Con sultation-paper-Standardised-Pan-European-Personal-Pension-product.pdf .

[6] Chen, L. et al. 2017. Small population bias and sampling effects in stochastic mortality modelling. Eur. Actuar. J., vol. 7, iss. 1, pp. 193-230. doi:10.1007/s13385-016-0143-x.

[7] Life tables 2017. [cit. 12-01-2017], www.statistics.sk/.

[8] Konicz, A. K. et al. 2015a. Optimal savings management for individuals with defined contribution pension plans. European Journal of Operational Research, vol. 243, iss. 1, pp. 233-247.

[9] Konicz, A. K. et al. 2015b. Optimal annuity portfolio under inflation risk. Comput Manag Sci.(2015), Springer-Verlag Berlin Heidelberg 2015, vol. 12, iss. 3, pp. 461-488.

[10] National Bank of Slovakia. 2013. The Order of the National Bank of Slovakia of 25 June 2013. [Vestník NBS z 25. júna 2013]. [cit.17-09-2016], http://www.nbs.sk/_img/ Documents/_Legislativa/_Vestnik/ciastka23V-2013.pdf

[11] National Bank of Slovakia. 2016. The Order of the National Bank of Slovakia of 1 December 2015. [Vestník NBS - opatrenie NBS č. 25/2015]. [cit. 11-01-2017], http://www.nbs.sk/_img/Documents/_Legislativa/_Vestnik/OPAT25-2015.pdf.

[12] Oxera 2012. [cit. 14-03-2012], http://www. oxera.com/main.aspx?id=14.

[13] The Human Mortality Database. 2017. [cit. 17-01-2017], http: //www .mortality . org/.

[14] The impact of a ban on the use of gender in insurance. 2012. [cit. 14-03-2012], http://www.slaspo.sk/tmp/asset_cache/link/0000033890/11207\%20oxera-stu dy-on-gender-use-in-insurance.pdf.

[15] Potocký, R. 2012. Modely v životnom a neživotnom poistení [Models in life and non-life insurance], STATIS, Bratislava, Slovakia. ISBN 978-80-85659-71-9.

[16] Urbaníková, M., Maroš, M. 2014. Finančná matematika [Financial Mathematics], Constantine The Philosopher University, Nitra, Slovakia. ISBN 978-8-055-80580-1. 